\begin{tabular}{|lcc|}
\hline & TOTOBUANG \\
\hline Volume 5 & Nomor 1, Juni 2017 & Halaman 19-32 \\
\hline
\end{tabular}

\title{
PREFIKS PEMBENTUK VERBA BAHASA KEPULAUAN TUKANG BESI DIALEK KALEDUPA (Prefiks Forming Verb Languages of Tukang Besi Dialect Kaledupa)
}

\author{
Iki Darno Masa Putra \\ Pascasarjana Universitas Hasanuddin \\ Tamalanrea Indah, Tamalanrea, Kota Makassar, Sulawesi Selatan 90245 \\ Pos-el: Ikidarnomasaputra@gmail.com
}

(Diterima: 9 Maret 2017; Direvisi 17 Maret 2017; Disetujui: 7 Juni 2017)

\begin{abstract}
This study examines verb forming prefixes in the Kaledupa dialect of the Kaledupa dialect. Selection of the title of this study based on observations and experiences of the author on the use of verb prefix in wakatobi society especially Kaledupa district as a whole. The theory used in this research is the generative morphology theory proposed by Halle using the principles and techniques of morpheme identification. Based on its kind, this research is a qualitative descriptive research type capable for various qualitative information with careful and nuanced descriptions to look carefully. The data of this research are oral data which is berafiks from informant. The method used in data analysis is refer to libat ably. The results of this study indicate the existence of verbforming prefixes in the Kaledupa dialect language of the Kaledupa dialect of the prefix $\{$ hon- $\},\{n o-\},\{p a-\},\{h e-$ \}, \{po\}-, \{ni-\}, \{heka-\}, dan \{to-\}.
\end{abstract}

Keywords: prefiks, verba, Dialek Kaledupa

\section{Abstrak}

Penelitian ini mengkaji Prefiks pembentuk verba dalam bahasa Kepulauan Tukang Besi dialek Kaledupa. Pemilihan judul penelitian ini berdasarkan pengamatan dan pengalaman penulis tentang penggunaan prefiks verba dalam lingkungan masyrakat Wakatobi khususnya kecamatan kaledupa secara keseluruhan.Teori yang digunakan dalam penelitian ini adalah Teori Morfologi generatif yang dikemukakan oleh Halle dengan menggunakan prinsip-prinsip dan teknik identifikasi morfem. Berdasarkan jenisnya, penelitian ini adalah jenis penelitian deskriptif kualitatif yang bertujuan untuk mengungkapkan berbagai informasi kualitatif dengan pendeskripsian yang teliti dan penuh nuansa untuk menggambarkan secara cermat. Data penelitian ini adalah data lisan berupa Verba berafiks yang dikumpulkan dari informan. Metode yang digunakan dalam analisis data adalah simak libat cakap. Hasil penelitian ini menunjukkan bahwa prefiks pembentuk verba dalam bahasa Kepulauan Tukang Besi dialek Kaledupa terdapat prefiks \{hon-\}, \{no-\}, \{pa-\}, \{he-\}, \{po\}-, \{ni-\}, \{heka-\}, dan\{to-\}.

Kata-kata Kunci: prefiks, verba, Dialek Kaledupa

\section{PENDAHULUAN}

Setiap bahasa memiliki sistem pembentukan kata jadian termasuk pembentukan kata kerja yang berbeda antara satu bahasa dengan bahasa yang lain. Penulis memilih Dialek Kaledupa sebagai objek penelitian karena Dialek Kaledupa merupakan bahasa penghubung dan pendukung kebudayaan daerah yang memiliki sejarah dan tradisi yang khas. Oleh karena itu, Dialek Kaledupa merupakan alat komunikasi yang tidak kalah pentingnya bagi masyarakat di Kepulauan Tukang Besi, khususnya di Pulau Kaledupa.

Bahasa Kepulauan Tukang Besi Dialek Kaledupa adalah salah satu bahasa daerah di Indonesia yang terdapat di Sulawesi Tenggara, tepatnya di Kabupaten Wakatobi. Bahasa ini digunakan sebagai sarana komunikasi bagi penduduk yang bermukim di Pulau Kaledupa tepatnya di Kecamatan Kaledupa dan Kecamatana Kaledupa Selatan. Penutur bahasa ini jumlahnya lebih kecil bila dibandingkan dengan bahasa 
daerah lain yang terdapat di Sulawesi Tenggara seperti Wolio dan Cia-cia.

Mengelompokkan bahasa daerah di Indonesia, menurut Kasseng (dalam Yuli, 2013: 2) dijelaskan bahwa Bahasa Kepulauan Tukang Besi termasuk dalam kelompok bahasa Muna Butung.Di daerah ini terdapat sejumlah dialek, diantaranya Dialek Wanci, Dialek Tomia, Dialek Kaledupa dan Dialek Binongko.

Berbagai upaya pengembangan dan pembinaan bahasa Kepulauan Tukang Besi guna mempertahankan keutuhan bahasa tersebut telah dilakukan walaupun masih dalam kondisi terbatas.

Upaya tersebut ditandai dengan adanya beberapa penelitian yang pernah dilakukan oleh peneliti sebelumnya, seperti yang dilakukan oleh Jaria pada tahun 1995 tentang "Sistem Derivasi dan Infleksi Bahasa Kepulauan Tukang Besi", Mulyono pada tahun 2004 tentang "Sistem Reduplikasi Bahasa Kepulauan Tukang Besi dialek Tomia”, Djamudi pada tahun 2005 tentang "Deskripsi Fonem Bahasa Kaledupa di Kepulauan Tukang Besi, Hasrina pada tahun 2012 tentang "Sistem Sapaan Bahasa Kepulauan Tukang Besi dialek Tomia", Lindawati pada tahun 2015 tentang "Kalimat Imperatif Bahasa Kepulauan Tukang Besi, dan Wo Ode Salmia Nur pada tahun 2015 tentang "Tipe-Tipe Semantik Adjektifa Bahasa Kepulauan Tukang Besi Dialek Kaledupa.

Penulis sebagai putra daerah di Pulau Kaledupa menyadari bahwa penelitian tentang Dialek Kaledupa masih sangat minim, sehingga Dialek Kepulauan sangat urgen untuk diteliti. Dialek Kaledupa memiliki keunikan tersendiri dalam hal proses afiksasi khususnya prefiks pembentukan kelas kata verba. Misalnya kata fatu 'batu' yang digabungkan dengan prefiks he-, no-, na-, dan po- dapat mengubah kelas kata. Kata fatu berkelas kata nomina dapat berubah menjadi verba ketika digabungkan denga prefiks tersebut di atas.
Melihat kenyataan tersebut, tepatlah jika penelitian prefiks pembentuk verba Bahasa Kepulauan Tukang Besi Dialek Kaledupa perlu segera dilaksanakan melengkapi tata bahasa Dialek Kaledupa.

Di samping itu, penelitian ini dapat memberi sumbangan positif dalam pembinaan dan pengembangan bahasa serta dapat menjadi acuan dalam penyusunan bahan ajar Muatan Lokal Bahasa Kepulauan Tukang Besi.

Fokus masalah penelitian ini berkaitan dengan aspek morfofonemik yakni mengenai prefiks pembentuk verba bahasa Kepulauan Tukang BesiDialek Kaledupa.

Tujuan penelitian ini adalah untuk mendeskripsikan proses afiksasi prefiks pembentuk Verba BahasaKepulauan Tukang Besi Dialek Kaledupa.

\section{LANDASAN TEORI}

Bahasa mempunyai sistem (Hill;1958:1, Uhlenbeck;1982:19).Sistem ini tercermin dalam kaidah bahasa yang bersangkutan. Karena penelitian ini mencakup bentuk dan proses prefiks. Maka dalam penelitian ini menggunakan teori Morfologi Generatif. Penulis akan bersandar pada pandangan Chomsky (1970), Parera (1994), Halle (1973).

Chomsky (1970) memulai langkah awal dalam memperkenalkan teori morfologi meneratif. Menu-rutnya, morfologi generatif merupakan sub bidang tata bahasa generatif transformasi. Parera (1994: 27) menjelaskan bahwa untuk memahami teknik dan proses analisis morfologi generatif perlu diingat kembali konsep kompetensi dan performansi, konsep struktur dalam dan struktur luar, komponen sintaksis berupa subkomponen basis dan subkomponen transformasi, komponen semantik, komponen fonologi, dan terakhir bahasa bersifat kreatif. Halle pada tahun 1973 merupakan salah seorang linguis yang memiliki minat besar dalam morfologi generatif menulis sebuah makalah yang berjudul “ Morphology In A Generative 
Grammer". Makalah ini disajikan pada Congres Of Linguistic di Bologna tahun 1972. Pada tahun berikutnya makalah ini diterbitkan dalam bentuk artikel dengan judul "Prologemena to a Theory of Word Formation". Dalam tulisannya, Hallen menjelaskan bahwa tataran morfologi memiliki tiga komponen yang tidak dapat dihilangkan salah satunya. Ketiga komponen tersebut adalah (1) daftar morfem (List Of Morphemis), (2) kaidah pembentukan kata (Word Formation Rules), dan (3) saringan (Filter).

Dari beberapa kajian yang telah dilakukan oleh Halle pada tahun 1973, Penulis akan menggunakan pandangannya, yaitu menggunakan prinsip-prinsip dan teknik identi-fikasi morfem. Komponen pertama adalah Daftar Morfem (DM) yang terdiri dari dua macamanggota yaitu morfem dan bermacam-macam afiks, baik yang derivasional maupun yang infleksional. Hallen menganggap bahwa satuan-satuan dasar leksikon adalah morfem. Contohnya dalam bahasa Inggris ditemukanmorfem write yang harus dijelaskan sebagai kata verbal.

Komponen kedua adalahkaidah pembentukan kata (KPK) yaitu bersamasama dengan morfem yang termuat dalam DM membentuk kata-kata, baik kata-kata yang benar-benar ada maupun bentuk "kata potensial" yaitu bentuk satuan lingual yang belum adadalam realitas tetapi mungkin akan ada karena memenuhi persyaratan KPK. Secara spesifik, KPK bertugas untuk membentuk kata-kata baru berdasarkan satuan-satuan dasar leksikon yang terdapt dalam DM. Misalnya kata derivation dan *derival dalam bahasa Inggris serta kata pemberiandan *berian, *berlayar dan *berbis.

Komponen ketiga adalah saringan yang bertugas menyaring kata bentukan yang diproses dalam komponen KPK melalui idiosinkresi, baik berupa idiosinkresi fonologis, idiosinkresi semantik, maupun idiosinkresi leksikal sehingga tidak semua kata dapat diturunkan dengan menggunakan KPK. Misalnya dalam idiosinkresi fonologis pada kata mempunyai. Sesuai dengan kaidah bahasa Indonesia jika konsonan /p/ yang berada di awal kata mendapat prefiks $\{m o N$ \}, maka konsonan $/ p /$ seharusnya luluh bila dibandingkan dengan meminjam. Bentuk dasar dari kedua kata itu adalah punya dan pukul. Untuk idiosinkresi semantik, terlihat pada kata perjuangan yang bermakna suat kegiatan yang bertaraf nasional atau kehidupan. Kemudian contoh idiosinkresi leksikal dapat dilihat pada kata-kata bentukan melalui KPK tidak menyalahi kaidah, tetapi dalam realitasnya kata-kata ini tidak pernah muncul pada percakapan sehari-hari. Kata-kata ini masuk kebentuk potensial, seperti *mencantik, *memperbetuli, dan sejenisnya. Dengan demikian, komponen ini dapat menjelaskan dan memberikan informasi mengapa bentuk lain tak dapat berterima. Kemudian, untuk menampung kata-kata hasil dari komponen KPK yang telah lolos dari komponen saringan, maka Halle menambahkan sebuah komponen, yaitu komponen dictionary atau kamus. Halle tidak menganggap komponen ini merupakan bagian integral dari morfologi generatif, sehingga di awal penjelasan hanya disebutkan tiga komponen. Walaupun demikian, komponen ini memiliki peranan dalam pembentukan kata karena leksikon yang terdapat dalam kamus dapat digunakan oleh KPK untuk diproses lagi seperti proses afiksasi sehingga dapat membentuk leksikon baru. Selain bentuk-bentuk yang lolos dari komponen saringan ada juga bentuk-bentuk yang tertahan dalam saringan atau tidak lolos yang disebut bentuk potensial. Halle tidak menjelaskan secara pasti di mana bentuk ini akan ditampung.Alur pembentukan kata dalam teori morfologi generatif oleh Halle dapat digambarkan pada diagram di bawah ini. 


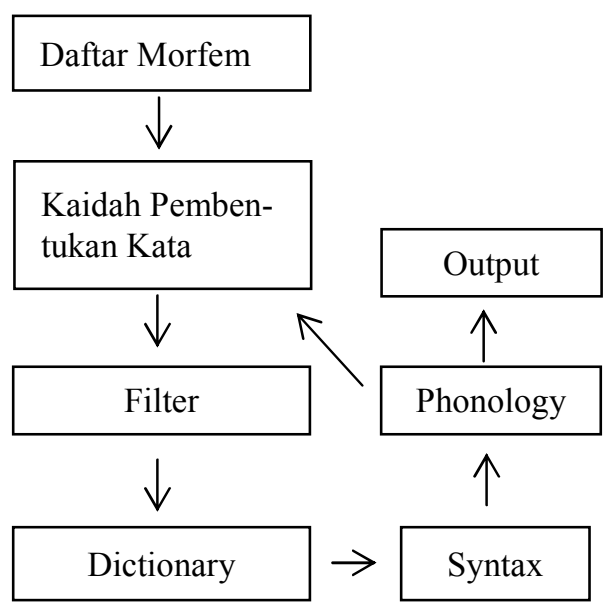

Diagram Morfologi Generatif Model Halle

\section{METODE}

Berdasarkan jenisnya, penelitian ini adalah penelitian deskriptif kualitatif. Penelitian deskriptif kualitatif bertujuan untuk mengungkapkan berbagai informasi kualitatif dengan pendeskripsian yang teliti dan penuh nuansa untuk menggambarkan secara cermat sifat-sifat suatu hal. (individu atau kelompok), keadaan, gejala atau fenomena yang lebih berharga daripada hanya pernyataan dalam bentuk angka-angka dan tidak terbatas pada pengumpulan data melainkan meliputi analisis dan interpretasi data Sutopo (1997: 8-10). Metode kualitatif adalah metode penelitian terhadap suatu masalah yang tidak dirangsang menggunakan prosedur-prosedur statistik. Metode ini bersifat deskriptif sehingga datanya berupa kalimat yang dianalisis dari segi kegramatikalannya dengan menggunakan teori atau pendekatan tertentu Subroto (1992: 5).

Metode penyediaan data yang digunakan dalam penelitian ini adalah metode simak libat cakap.

Menurut Mahsun (2007:92), metode simak merupakan metode yang digunakan untuk memperoleh data dengan menyimak penggunaan bahasa. Teknik dasar metode simak dilakukan dengan penyadapan. Dalam arti, peneliti dalam upaya mendapatkan data dilakukan dengan menyadap penggunaan bahasa oleh informan. Perlu ditekankan bahwa menyadap penggunaan bahasa yang dimaksudkan menyangkut pengguna-an bahasa, baik secara lisan maupun tertulis.

Metode simak menurut Sudaryanto (1993:133) mencakup teknik sebagai berikut: (1) teknik sadap, secara praktis metode simak dilakukan dengan penyadapan. Seorang peneliti dalam rangka mendapatkan data, ia harus menggunakan kecerdikannya untuk menyadap pembicaraan informan; (2) teknik simak libat cakap, dalam kegiatan menyadap seorang peneliti harus berpartisipasi dalam pembicaraan dan menyimak pembicaraan, sehingga peneliti melakukan dialog secara langsung dengan informan.

Teknik simak libat cakap maksudnya melakukan penyadapan dengan cara berpartisipasi sambil menyimak, berpartisipasi dalam pembicaraan, dan menyimak pembicaraan. dalam hal ini, penulis terlibat langsung dalam dialog. Adapun teknik simak libat cakap, maksudnya peneliti hanya berperan sebagai pengamat penggunaan bahasa oleh informannya. Penulis hanya terlibat dalam periistiwa yang bahasanya sedang diteliti

Sumber data penelitian ini adalah data lisan, maka teknik lanjutan yang digunakan adalah teknik catat.Dalam penyadapan itu peneliti hanya dapat menggunakan teknik catat sebagai gandengan teknik simak bebas libat cakap, yaitu mencatat beberapa bentuk yang relevan bagi penelitiannya dari penggunaan bahasa secara tertulis tersebut.

\section{PEMBAHASAN}

Bahasa Kepulauan Tukang Besi Dialek Kaledupa terdapat sembilan prefiks pembentuk verba. Prefiks tersebut terdiri atas prefix $\{$ hon-\}, \{no-\}, \{pa-\}, \{he-\}, \{po-\}, $\{n i-\}$, \{heka-\}, dan \{to-\}. Selanjutnya bentuk tersebut direalisasikan dengan bentuk turunan atau dengan bentuk alomorf tergantung bunyi awal kata dasar yang diawali yang dikenal dengan proses morfofonemik. Perhatikan tabel di bawah ini. 
Tabel 1

Proses Morfofenemik

\begin{tabular}{|c|c|c|}
\hline No & Prefiks & Contoh \\
\hline \multirow[t]{8}{*}{1} & Hon- & \\
\hline & $\begin{array}{l}\text { Hon- } \\
\mathrm{t}, \\
\mathrm{k},\end{array}$ & $\begin{array}{l}\text { Honampoli } \\
\text { Honeke }\end{array}$ \\
\hline & $\begin{array}{l}\text { Hongo- } \\
\mathrm{k},\end{array}$ & Hongokire \\
\hline & $\begin{array}{l}\text { Honon } \\
\mathrm{t},\end{array}$ & Honontaho \\
\hline & $\begin{array}{l}\text { Homo- } \\
\mathrm{n}, \\
1,\end{array}$ & $\begin{array}{l}\text { Homonihi } \\
\text { Homoleka }\end{array}$ \\
\hline & $\begin{array}{l}\text { Hoko } \\
\text { d, } \\
\text { l, }\end{array}$ & $\begin{array}{l}\text { Hokodao } \\
\text { Hokoleama }\end{array}$ \\
\hline & $\begin{array}{l}\text { Hongam- } \\
\mathrm{P}\end{array}$ & Hongampale \\
\hline & $\begin{array}{l}\text { Hong- } \\
\mathrm{K}\end{array}$ & Hongangkaru \\
\hline \multirow[t]{2}{*}{2} & No- & \\
\hline & $\begin{array}{l}\mathrm{i}, \\
\mathrm{t}, \\
1,\end{array}$ & $\begin{array}{l}\text { Noita } \\
\text { Notange } \\
\text { Nolanda }\end{array}$ \\
\hline \multirow[t]{2}{*}{3} & $\mathrm{~Pa}-$ & \\
\hline & $\begin{array}{l}\mathrm{b}, \\
\mathrm{c}, \\
\mathrm{d}, \\
\mathrm{f}, \\
\mathrm{g}, \\
\mathrm{h}, \\
\mathrm{j}, \\
\mathrm{k}, \\
\mathrm{p}, \\
\mathrm{t}, \\
\mathrm{a}, \\
\mathrm{i}, \\
\mathrm{u}, \\
\mathrm{e}, \\
\mathrm{o}, \\
\mathrm{r},\end{array}$ & $\begin{array}{l}\text { Pabbalu } \\
\text { Paccaka } \\
\text { Paddoito } \\
\text { paffila } \\
\text { paggolu } \\
\text { pahhoja } \\
\text { pajjoge } \\
\text { pakkanalako } \\
\text { pappotaru } \\
\text { pattange } \\
\text { paala } \\
\text { paila } \\
\text { pantanga } \\
\text { paelo } \\
\text { paolo } \\
\text { paru }\end{array}$ \\
\hline \multirow[t]{2}{*}{4} & $\mathrm{He}-$ & \\
\hline & $\begin{array}{l}\mathrm{b}, \\
\mathrm{f}, \\
\mathrm{l},\end{array}$ & $\begin{array}{l}\text { Hebakaki } \\
\text { Hefatu } \\
\text { Helinda } \\
\end{array}$ \\
\hline 5 & Po- & \\
\hline
\end{tabular}

\begin{tabular}{|l|l|l|}
\hline & 1, & Polinda \\
& s, & Posepa \\
& b, & Pobalo \\
\hline $\mathbf{6}$ & Ni- & \\
\hline & k, & Nikabi \\
& b, & Nibasa \\
& l, & Nilaha \\
\hline $\mathbf{7}$ & Heka- & \\
\hline & f, & Hekafou \\
& o, & Hekaopi \\
& a, & hekaappa \\
\hline $\mathbf{8}$ & To- & \\
\hline & i, & Tointe \\
& m, & Tomanga \\
& k & Tokoni \\
\hline & & \\
\hline
\end{tabular}

Dari tabel di atas dapat disimpulkan bahwa prefiks \{hon-\} tidak mengalami perubahan apabila diikuti oleh bentuk dasar yang berawalan bunyi $/ \mathrm{t} / \mathrm{dan} / \mathrm{k} /$; menjadi \{honon-\} jika diikuti bentuk dasar yang berawalan /t/ (hanya pada kata dasar 'taho' mnejadi honontaho); menjadi \{homo-\} jika diikuti oleh bentuk dasar berbunyi awalan /n/ dan /1/; menjadi \{hoko-\} jika diikuti oleh bentuk dasar berbunyi awalan /d/ dan /1/; menjadi \{hongam-\} jika diikuti oleh bentuk dasar berbunyi awalan /p/ dan /t/; menjadi \{hong-\} jika diikuti oleh bentuk dasar berbunyi awalan $/ \mathrm{k} /$; menjadi \{hong\} jika diikuti oleh bentuk dasar berbunyi awalan $/ \mathrm{k} /$.

Prefiks \{no- $\}$ tidak mengalami perubahan jika diikuti oleh bentuk dasar berbunyi awalan /i/, /t/, dan /1/.prefiks \{pa- $\}$ mengalami perubahan bentuk yaitu penambahan fonem yang sama jika fonem kata dasar yang berawalan bunyi /b/, /c/, /d/, /f/, /g/, /h/, /j/, /k/, /p/, dan /t/.Prefiks \{hetidak mengalami perubahan jika diikuti oleh bentuk dasar berbunyi awalan /b/, /f/, dan /1/.Prefiks \{po-\} tidak mengalami perubahan jika diikuti oleh bentuk dasar berbunyi awalan /1/, /s/, dan /b/.Prefiks \{ni-\} tidak mengalami perubahan jika diikuti oleh bentuk dasar berbunyi awalan $/ \mathrm{k} /, / \mathrm{b} /$, dan /1/.Prefiks \{heka- $\}$ tidak mengalami 
perubahan jika diikuti oleh bentuk dasar berbunyi awalan /f/, /o/, dan /a/.Prefiks \{to- $\}$ tidak mengalami perubahan jika diikuti oleh bentuk dasar berbunyi awalan $/ \mathrm{i} /, / \mathrm{m} /$, dan $/ \mathrm{k} /$.

\section{Verba berprefiks $\{h o N-\}$}

Proses afikasasi prefiks $\{h o N-\}$ dalam Dialek Kaledupa dapat mengubah kelas kata dasar menjadi kelas kata verba atau tidak mengubah sama sekali.

Pembentukan kata yang menggunakan prefiks $\{h o N-\}$ dapat berubah sesuai dengan kondisi yang mengikutinya. Prefiks $\{h o N-\}$ mempunyai beberapa bentuk yaitu $\{h o n-\}$, \{hong-\}, \{hongo-\}, \{honon-\}, \{homo-\}, \{hoko-\}, \{hongam-\}. Ketujuh bentuk perubahan prefiks $\{h o N-\}$ tersebut disebut alomorf dari prefiks $\{h o N-\}$.

\section{a. Prefiks $\{$ hon- $\}$}

Bentuk dasar dalam pembentukan verba dengan prefiks \{hon-\}berupa morfem dasar bebas seperti terdapat pada kata honampoli, honappori dan honeke. Bentuk dasarnya berupa morfem dasar bebas: tampoli, tappori, dan keke.

\begin{tabular}{|c|c|c|}
\hline $\begin{array}{l}\text { (1) tampoli } \\
\text { 'tambal' }\end{array}$ & $\rightarrow$ & $\begin{array}{l}\text { honampoli } \\
\text { 'menambal' }\end{array}$ \\
\hline $\begin{array}{l}\text { (2) tappori } \\
\text { 'bakar' }\end{array}$ & - & $\begin{array}{l}\text { honappori } \\
\text { 'membakar' }\end{array}$ \\
\hline $\begin{array}{l}\text { 3) keke } \\
\text { gali' }\end{array}$ & & $\begin{array}{l}\text { honeke } \\
\text { 'menggal }\end{array}$ \\
\hline
\end{tabular}

Prefiks \{hong-\}berfungsi sebagai kata kerja atau melakukan pekerjaan.Ketiga contoh prefiks di atas mengalami peluluhan fonem pada awal kata dasar. Data (1) terbentuk dari gabungan prefiks \{hon-\} dengan kata dasar tampoli 'tambal' yaitu honampoli 'menambal' mengalami peluluhan pada /t/. Data (2) merupakan gabungan dari prefiks \{hon- $\}$ dengan kata dasar tappoli 'bakar' yaitu honappoli "membakar' mengalami peluluhan /t/ di awal kata dasar. Data (3) terbentuk dari gabungan prefiks \{hon-\} dan kata dasar keke 'gali yaitu hongeke 'menggali' mengalami peluluhan pada $/ \mathrm{k} /$.

Terdapat sejumlah verba yang tidak dapat bergabung dengan prefiks \{hon-\}, misalnya:

$$
\begin{aligned}
& \text { tinti } \rightarrow \quad * \text { honinti } \\
& \text { tuttu } \rightarrow \text { *honuttu } \\
& \text { 'tumbuk' } \\
& \underset{\text { teriak' }}{\text { kingki }} \rightarrow \text { *honingki }
\end{aligned}
$$

\section{b. Prefiks $\{$ hong- $\}$}

Bentuk dasar dalam pembentukan verba dengan prefiks \{hong-\}berupa morfem dasar bebas seperti terdapat pada kangkaru dan kuppa. Bentuk dasarnya berupa morfem dasar bebas: kangkaru, kuppa, dan kusso.

$$
\begin{array}{r}
\text { (1) kangkaru } \rightarrow \text { hongangkaru } \\
\text { 'mencakar' }
\end{array}
$$

(2) kuppa $\rightarrow$ honguppa 'tangkap' 'menangkap'

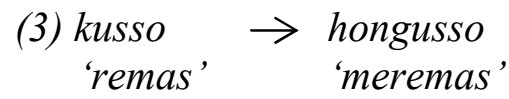

Prefiks \{hongo-\} bermakna melakukan kegiatan atau pekerjaan. Prefiks hongotidak produktif. Data (1) dibentuk dari prefiks \{hong-\} digabungkan dengan kata dasar kangkaaru 'cakar' menjadi hongangkaru 'mencakar'. Kata hongangkaru mengalami peluluhan $/ \mathrm{k} /$ pada kata dasarnya. Data (2) terbentuk dari gabungan prefiks \{hong-\} dengan kata dasar kuppa 'tangkap'. Kata honguppa mengalami peluluhan pada /k/ awal kata dasar. Data (3) terbentuk dari gabungan prefiks \{hong-\} dengan kata dasar kusso'remas' yaitu hongusso'meremas'. Kata hongusso mengalami peluluhan pada $/ \mathrm{k} /$ awal kata dasar. 
Verba di bawah ini tidak bisa bergabung dengan prefiks \{hong-\}. Misalnya:

kaho
garuk'
$\begin{aligned} & \text { kindu } \\ & \text { gerak' }\end{aligned}$
$\begin{aligned} & \text { kopu } \\ & \text { 'peluk' }\end{aligned}$

\section{c. Prefiks \{hongo-\}}

Bentuk dasar dalam pembentukan verba dengan prefiks \{hongo-\}berupa morfem dasar bebas seperti terdapat pada hongokahodan hongokire. Bentuk dasarnya berupa morfem dasar bebas: kaho dan kire.

$$
\begin{aligned}
& \begin{array}{c}
\text { (1) kaho } \\
\text { garuk' }
\end{array} \\
& \begin{array}{c}
\text { hongokaho } \\
\text { 'menggaruk' } \\
\text { 'alise }
\end{array}
\end{aligned}
$$

Prefiks \{hongo-\} bermakna melakukan pekerjaan atau kegiatan.Data (1) terbentuk dari prefiks \{hongo-\}digabungkan dengan kata dasar kaho 'garuk yaitu hongokaho 'menggaruk. Kata hongokaho berkategori verba. Data (2) terbentuk dari gabungan prefiks \{hongo-\} dengan kata dasar kire 'alis' yaitu hongokire 'bermain alis'. Kata hongokire berkategori verba.

Prefiks \{hongo-\} ternyata tidal lazim melekat pada morfem-morfem berikut.

mbale $\rightarrow$ *hongombale 'baring'

$$
\begin{aligned}
& \underset{\text { berdiri }}{\text { tade }} \rightarrow \text { *hongotade } \\
& \begin{array}{l}
\text { huppu } \\
\text { tiup' }
\end{array} \rightarrow \text { *hongohuppu }
\end{aligned}
$$

\section{d. Prefiks \{honon-\}}

Bentuk dasar dalam pembentukan verba dengan prefiks \{honon-\}berupa morfem dasar bebas seperti terdapat pada honontahodan honontano. Bentuk dasarnya berupa morfem dasar bebas: taho dan tano.

$$
\begin{aligned}
& \text { (1) taho } \begin{array}{l}
\text { jerat' } \\
\text { (2) tano } \\
\text { 'tanam' }
\end{array} \rightarrow \begin{array}{c}
\text { honontaho } \\
\text { 'menjerat' }
\end{array} \\
& \text { 'monontano }
\end{aligned}
$$

Prefiks \{honon-\} bermakna melakukan pekerjaan atau kegiatan.Data (1) terbentuk dari prefiks \{honon-\}digabungkan dengan kata dasar taho 'jerta' yaitu honontaho'menjerat. Kata honontahoberkategori verba. Data (2) terbentuk dari gabungan prefiks \{honon-\} dengan kata dasar tano 'tanam' yaitu honontano 'menanam'. Kata honontano berkategori verba.

Verba-verba di bawah ini tidak lazim mendapatkan prefiks \{honon-\}.

$$
\begin{aligned}
& \text { ila }{ }^{\text {hilang' }} \\
& \begin{array}{l}
\text { mai } \\
\text { 'datang' }
\end{array} \\
& \begin{array}{l}
\text { ekka } \\
\text { 'naik' }
\end{array}
\end{aligned}
$$

\section{e. Prefiks \{homo-\}}

Bentuk dasar dalam pembentukan verba dengan prefiks \{homo-\}berupa morfem dasar bebas seperti terdapat pada homonihidan homoleka. Bentuk dasarnya berupa morfem dasar bebas: nihidan leka.

$$
\begin{aligned}
& \text { (1) } \underset{\text { 'mihi }}{\text { mimpi' }} \rightarrow \\
& \begin{array}{l}
\text { homonihi } \\
\text { 'bermimpi' } \\
\text { 'buka' }
\end{array}
\end{aligned} \rightarrow \begin{aligned}
& \text { homoleka } \\
& \text { 'membuka' }
\end{aligned}
$$

Prefiks \{homo-\} bermakna atau berfungsi melakukan kegiatan. Prefiks \{homo-\} terbatas ketika bergabung dengan katadasar. Data (1) dibentuk dari prefiks 
\{homo-\} digabungkan dengan kata dasar nihi 'mimpi' menjadi homonihi 'bermimpi'. Data (2) terbentuk dari gabungan prefiks \{homo-\} dengan kata dasar leka'buka' yaitu homoleka'membuka'. Data (1) dan (2) berkategori verba.

Adapunn verba-verba seperti di bawah ini tidal lazim dilekati prefiks \{homo-\}.

bassi $\rightarrow$ *homobassi
'tukar' $\rightarrow$ *homosai
'buat' $\rightarrow$ *homorodongo
rodongo $\rightarrow$ 'dengar'

\section{f. Prefiks \{hoko-\}}

Bentuk dasar dalam pembentukan verba dengan prefiks \{hoko-\}berupa morfem dasar bebas seperti terdapat pada hokoda-o dan hokoleama. Bentuk dasarnya berupa morfem dasar bebas: da-o dan leama.

$$
\begin{aligned}
\text { (1) } \text { da-o }_{\text {rusak' }}, & \rightarrow \quad \begin{array}{c}
\text { hokoda-o } \\
\text { 'merusak' }
\end{array} \\
\text { (2) leama } & \rightarrow \quad \begin{array}{c}
\text { hokoleama } \\
\text { 'baik' }
\end{array},
\end{aligned}
$$

Prefiks \{hoko-\}bermakna melakukan pekerjaan. Data (1) dibentuk dari prefiks \{hoko-\} digabungkan dengan kata dasar da-o 'rusak' menjadi hoko da-o 'merusak'. Data (2) terbentuk dari gabungan prefiks \{hoko-\} dengan kata dasar leama'baik' yaitu hokoleama 'memperbaiki'. Kedua data di atas berkategori verba.

Prefiks \{hoko-\} tidak lazim melekati verba-verba dasar berikut:

$$
\begin{aligned}
& \underset{\text { tullu }}{\text { bantu' }} \rightarrow \text { *hokotullu } \\
& \underset{\text { banta }}{\text { bantah' }} \rightarrow \\
& \text { poafa } \\
& \text { 'jumpa' }
\end{aligned}
$$

\section{g. Prefiks \{hongam-\}}

Bentuk dasar dalam pembentukan verba dengan prefiks \{hongam-\}berupa morfem dasar bebas seperti terdapat pada hongampale. Bentuk dasarnya berupa morfem dasar bebas: pale.

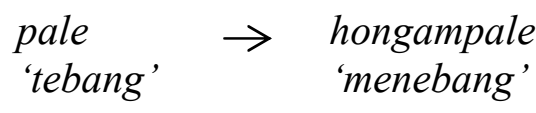

Prefiks \{hongam-\}tidakproduktif dan hanya pada katadasar tertentu. Data di atas dibentuk dari prefiks \{hongam-\} digabungkan dengan kata dasar pale 'tebang' menjadi hongampale 'menebang'. Kata honganmpale berkategori verba.

Verba-verba seperti di bawah ini tidak lazim mendapatkan prefiks \{hongam-\}.

$$
\begin{aligned}
& \text { bafa } \\
& \text { bawa' } \\
& \begin{array}{l}
\text { baha } \\
\text { 'cari' }
\end{array} \\
& \begin{array}{l}
\text { kahu } \\
\text { kirim' }
\end{array}
\end{aligned}
$$

\section{Prefiks $\{$ no- $\}$}

Prefiks \{no- $\}$ tidak mengalami perubahan bentuk pada saat digabungkan dengan bentuk lain. Pengimbuhannya dilakukan dengan cara merangkaikannya di depan kata yang diimbuhinya.

Bentuk dasar dalam pembentukan verba dengan prefiks \{no-\}berupa morfem dasar bebas seperti terdapat pada noita, notanga dan nolanda. Bentuk dasarnya berupa morfem dasar bebas: ita, tange dan landa.

$$
\begin{aligned}
& \begin{array}{l}
\text { (1) ita } \\
\text { 'lihat' }
\end{array} \rightarrow \text { noita } \text { 'melihat' } \\
& \text { (2) tange } \rightarrow \text { notange } \\
& \text { 'rokok' 'merokok' }
\end{aligned}
$$




\section{(3) Landa $\rightarrow$ nolanda 'injak' 'menginjak'}

Prefiks $\{n o-\}$ bermakna melakukan pekerjaan. Data (1) dibentuk dari prefiks $\{$ no\} digabungkan dengan kata dasar ita 'lihat' menjadi noita 'melihat'. Kata noita 'melihat' berkategori verba. Data (2) terbentuk dari gabungan prefiks $\{n o-\}$ dengan kata dasar tange'rokok' yaitu notange 'merokok'. Data (3) terbentuk dari prefiks \{no-\} digabungkan dengan kata dasar landa 'injak' menjadi nolanda 'menginjak'.

Prefiks $\{n o-\}$ tidak dapat melekati kata dasar sebagai berikut.

$$
\begin{aligned}
& \begin{array}{l}
\text { Boku } \\
\text { 'boku' }
\end{array} \\
& \begin{array}{l}
\text { intenga } \\
\text { jalanan' }
\end{array} \\
& \begin{array}{l}
\text { baju } \\
\text { tukar' }
\end{array}
\end{aligned}
$$

\section{Prefiks $\{p a-\}$}

Prefiks $\{p a-\}$ mengalami penambahan fonem yang sama terhadap $/ \mathrm{b} /, / \mathrm{c} /, / \mathrm{d} /, / \mathrm{f} /$, $/ \mathrm{g} /, / \mathrm{h} /, / \mathrm{j} /, / \mathrm{k} /, / 1 /, / \mathrm{n} /, / \mathrm{m} /, / \mathrm{s} /, / \mathrm{p} /, / \mathrm{t} /$, pada awal bentuk dasar morfem. Prefiks Pamemiliki makna "sering,dan melakukan pekerjaan"

Bentuk dasar dalam pembentukan verba dengan prefiks $\{p a-\}$ berupa morfem dasar bebas seperti terdapat pada pabbalu, paccaka paddoito, paffila, paggolu, pahhoja, pajjoge, pakkanalako, pappotaru, dan pattange,. Bentuk dasarnya berupa morfem dasar bebas: balu, caka, doito, fila, golu, hoja, joge, kanalako dan potaru.
(1) balu $\rightarrow$ pabbalu 'beli' 'seringmembeli'
(2) caka $\rightarrow$ paccaka 'gurau' 'bergurau'
(3) doito $\rightarrow$ paddoito 'menangis' 'seringmenangis'
(4) fila $\rightarrow$ paffila
'Jalan' 'seringjalan'
(5) golu $\rightarrow$ paggolu 'bola' 'sering main bola'
(6) hoja $\rightarrow$ pahhoja 'bohong' 'berbohong'
(7) joge $\rightarrow$ pajjoge 'joget' 'sering joget'
(8) kanalako $\rightarrow$ pakkalano 'curi' 'seringmencuri'
(9) potaru $\rightarrow$ pappoptaru 'Judi' 'sering judi'
(10) tange $\rightarrow$ pattange 'rokok' 'sering merokok'

Prefiks $\left\{\mathrm{Pa}_{-}\right\}$mempunyai variasi bentuk sesuai dengan kondisi morfem yang mengikutinya. Prefiks $\{p a-\}$ berfungsi sebagai kata kerja atau sering melakukan pekerjaan.

Data (1) terbentuk dari prefiks $\{p a-\}$ digabungkan dengan kata dasar balu 'beli' menjadi pabbalu 'sering membeli'. Data (2) terbentuk dari prefiks $\{p a-\}$ digabungkan dengan kata dasar caka 'gurau' menjadi paccaka 'bergurau'.Data (3) terbentuk dari prefiks $\{p a-\}$ digabungkan dengan kata dasar doito'tangis' menjadi paddoito 'sering menangis'.Data (4) terbentuk dari prefiks $\{p a-\}$ digabungkan dengan kata dasar fila 'jalan' menjadi paffila 'sering jalan'. Data (5) terbentuk dari prefiks $\{p a-\}$ digabungkan dengan kata dasar golu 'bola' menjadi paggolu 'sering bermain bola'. Data (6) terbentuk dari prefiks $\{p a-\}$ digabungkan dengan kata dasar hoja 'bohong' menjadi pahhoja 'berbohong'. Data (7) terbentuk dari prefiks $\{p a-\}$ digabungkan dengan kata dasar joge 'joget' menjadi pajjoge 'sering berjoget'.Data (8) terbentuk dari prefiks $\{p a-$ \} digabungkan dengan kata dasar kanalako 
'curi' menjadi pakkanalako 'sering mencuri'.Data (9) terbentuk dari prefiks \{pa\} digabungkan dengan kata dasar potaru 'judi' menjadi pappotaru 'sering menjudi'. Data (10) terbentuk dari prefiks $\{p a-\}$ digabungkan dengan kata dasar tange 'rokok' menjadi pattange 'sering merokok'. Semua data (1) sampai (4) berkategori verba.

Prefiks \{pa-\} tidak dapat melekati verba-verba dasar sebagai berikut.

$$
\begin{aligned}
& \text { bansi } \begin{array}{l}
\text { 'hina' } \\
\text { Munculu } \\
\text { 'muncu'l }
\end{array} \\
& \begin{array}{l}
\text { tukkara } \\
\text { 'tukar' }
\end{array} \\
& \begin{array}{l}
\text { kaluara } \\
\text { 'keluar' }
\end{array} \\
& \text { tade } \\
& \text { 'berdiri' }
\end{aligned}
$$

Prefiks $\{\mathrm{Pa}$ - $\}$ tidak mempunyai variasi bentuk sesuai dengan kondisi morfem yang mengikutinya jika bergabung morfem berawal fonem vokal $(\mathrm{a}, \mathrm{i}, \mathrm{u}, \mathrm{e}, \mathrm{o}), / \mathrm{r} / \mathrm{awal}$ bentuk dasar morfem.Prefiks $\left\{\mathrm{Pa}_{-}\right\}$ mempunyai makna "sering dan melakukan pekerjaan".

\begin{tabular}{|c|c|c|}
\hline $\begin{array}{l}\text { (1) ala } \\
\text { 'Ambil', }\end{array}$ & $\rightarrow$ & $\begin{array}{l}\text { paala } \\
\text { 'sering mengambil }\end{array}$ \\
\hline $\begin{array}{l}\text { (2) ila } \\
\text { 'hilang' }\end{array}$ & $\rightarrow$ & $\begin{array}{l}\text { paila } \\
\text { 'menghilang' }\end{array}$ \\
\hline $\begin{array}{l}\text { (3) ntanga } \\
\text { 'bunyi' }\end{array}$ & & $\begin{array}{l}\text { pantanga } \\
\text { 'berbunyi' }\end{array}$ \\
\hline
\end{tabular}

Bentuk dasar dalam pembentukan verba dengan prefiks $\{p a-\}$ berupa morfem dasar bebas seperti terdapat pada paala, paila, pantanga, paupa, paolo, dan paru Bentuk dasarnya berupa morfem dasar bebas: ala, ila, ntanga, upa, olo, dan ru.
(4) upa $_{\text {'umpan' }} \rightarrow \quad$ Paupa
'memberi umpan'

(5) olo $\rightarrow$ paolo

'libur' 'sering berlibur'

(6) $r u \rightarrow$ paru

'bunyi' 'membunyikan'

Data (1) terbentuk dari prefiks $\{p a-\}$ digabungkan dengan kata dasar ala 'ambil' menjadi paala 'sering mengambil'.Data (2) terbentuk dari prefiks $\{p a-\}$ digabungkan dengan kata dasar ila 'hilang' menjadi paila ' sering menghilang'. Data (3) terbentuk dari prefiks $\{p a-\}$ digabungkan dengan kata dasar ntanga 'bunyi' menjadi pantanga 'membunyikan'. Data (4) terbentuk dari prefiks $\{p a-\}$ digabungkan dengan kata dasar upa 'umpan' menjadi paru 'memberi umpan'. Data (5) terbentuk dari prefiks $\{p a-\}$ digabungkan dengan kata dasar olo 'libur' menjadi paolo 'sering libur'.Data (6) terbentuk dari prefiks $\{p a-\}$ digabungkan dengan kata dasar ru 'bunyi' menjadi paru 'mem-bunyikan'.

\section{Prefiks $\{h e-\}$}

Dalam pembentukan kata, prefiks \{hettidak mengalami perubahan bentuk. Pengimbuhannya dilakukan dengan cara merangkaikannya di depan kata yang diimbuhinya. Prefiks \{he-\}mempunyai makna melakukan pekerjaan. Bentuk dasar dalam pembentukan verba dengan prefiks \{he-\}berupa morfem dasar bebas seperti terdapat pada hebakaki, hefatu, dan helinda. Bentuk dasarnya berupa morfem dasar bebas: bakaki, fatu, dan linda.

$$
\begin{aligned}
& \begin{array}{c}
\text { Contoh: } \\
\text { bakaki } \\
\text { 'Kopra' }
\end{array} \\
& \begin{array}{c}
\text { hatu } \\
\text { 'Batu' }
\end{array}
\end{aligned} \rightarrow \begin{aligned}
& \text { hebakakiatu kopra' } \\
& \text { 'mencari batu' }
\end{aligned}
$$


Linda $\rightarrow$ helinda

'Pindah' 'berpindah'

Adapun kata dasar yang tidak lazim dilekati oleh prefiks \{he-\} sebagai berikut.

laha $\rightarrow$ *helaha
'cari'u $\rightarrow$ *hehu'u
'beri'
maso
'masuk'

\section{Prefiks $\{p o-\}$}

Prefiks $\left\{\mathrm{Po}_{-}\right\}$tidak mengalami perubahan bentuk pada saat digabungkan dengan kata dasar. Prefiks Po- hanya melekat pada kata kerja dan katasifat. Prefiks \{po-\}bermakna melakukan pekerjaan, kegiatan dan saling.

Bentuk dasar dalam pembentukan verba dengan prefiks \{po-\}berupa morfem dasar bebas seperti terdapat pada polinda, posepa dan pobalo. Bentuk dasarnya berupa morfem dasar bebas: linda, sepa dan balo.

$$
\begin{aligned}
& \text { (1) } \begin{array}{l}
\text { linda } \rightarrow \\
\text { 'pindah' }
\end{array} \\
& \begin{array}{c}
\text { polinda } \\
\text { 'berpindah' }
\end{array} \\
& \begin{array}{c}
\text { (2) sepa } \\
\text { tendang' }
\end{array} \\
& \begin{array}{c}
\text { posepa } \\
\text { (3) baling tendang' } \\
\text { 'sahut' }
\end{array}
\end{aligned}
$$

Data (1) dibentuk dari prefiks $\{p o-\}$ digabungkan dengan kata dasar linda 'pindah' menjadi polinda 'berpindah'. Data (2) dibentuk dari prefiks $\{p o-\}$ digabungkan dengan kata dasar sepa 'tendang' menjadi posepa 'saling tendang'.Data (3) dibentuk dari prefiks \{po-\} digabungkan dengan kata dasar balo 'sahut' menjadi pobalo 'saling sahut'.

Prefiks \{po-\}tidak dapat melekat pada verba-verba dasar dasar sebagai berikut.

$$
\text { nangu } \rightarrow \text { *ponangu }
$$

'senang'

$$
\begin{aligned}
& \begin{array}{l}
\text { basa } \\
\text { baca' }
\end{array} \\
& \begin{array}{l}
\text { inte } \\
\text { pergi, }
\end{array}
\end{aligned}
$$

\section{Prefiks \{ni-\}}

Prefiks $\quad\{n i\}$-tidak mengalami perubahan bentuk. Bentuk dasar dalam pembentukan verba dengan prefiks $\{n i-$ fberupa morfem dasar bebas seperti terdapat pada nikabi dannibasa. Bentuk dasarnya berupa morfem dasar bebas: kabi dan basa

$$
\begin{aligned}
& \begin{array}{l}
\text { kabi } \\
\text { buang' } \rightarrow \quad \text { nikabi } \\
\text { 'dibuang' }
\end{array} \\
& \text { (1) basa } \rightarrow \text { nibasa } \\
& \text { 'baca' 'dibaca' } \\
& \begin{array}{l}
\text { (2) } \begin{array}{l}
\text { laha } \\
\text { 'cari }
\end{array} \rightarrow \text { 'dicari' } \\
\text { 'dica }
\end{array}
\end{aligned}
$$

Prefiks ni-berfungsi membentuk kata

\begin{tabular}{|c|c|c|}
\hline $\begin{array}{l}\text { inte } \\
\text { 'pergi' }\end{array}$ & $\rightarrow$ & *niinte \\
\hline inte & $\rightarrow$ & niintesi \\
\hline $\begin{array}{l}\text { fila } \\
\text { jalan, }\end{array}$ & $\rightarrow$ & ${ }^{*}$ nifila \\
\hline fila & $\rightarrow$ & nifilasi \\
\hline $\begin{array}{l}\text { sau } \\
\text { minta }\end{array}$ & & *nisau \\
\hline
\end{tabular}
kerja pasif atau "dikenai laku dan tindakan”.Data (1) terbentuk dari prefiks \{ni\} digabungkan dengan kata dasar kabi 'buang' menjadi nikabi 'dibuang'. Data (2) terbentuk dari prefiks $\{n i-\}$ digabungkan dengan kata dasar basa 'baca' menjadi nibasa 'dibaca'.Data (3) terbentuk dari prefiks $\{n i-\}$ digabungkan dengan kata dasar laha 'cari' menjadi nilaha 'dicari'. Ketiga data di atas berkategori verba.

Prefiks \{ni-\}tidak dapat melekat pada verba-verba dasar dasar sebagai berikut. 


\section{Prefiks \{heka-\}}

Prefis \{heka-\}tidak memiliki perubahan bentukketika bergabung dengan kata dasar.Bentuk dasar dalam pembentukan verba dengan prefiks \{heka-\}berupa morfem dasar bebas seperti terdapat pada hekafou, hekaappa, dan hekaopi.Bentuk dasarnya berupa morfem dasar bebas: appa, fou, dan opi.

$$
\begin{aligned}
& \text { (1) fou } \rightarrow \text { hekafou } \\
& \text { 'Pancing' 'memancing' }
\end{aligned}
$$

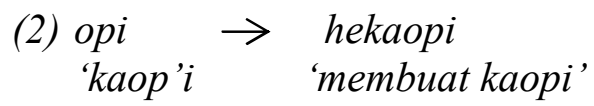

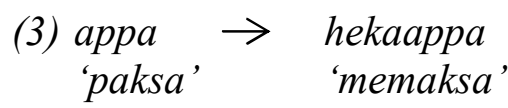

Prefiks \{heka-\} bertujuan untuk makna "melakukan kegiatan".Ketiga data di atas memiliki makna dan pembentukan verba yang sama. Data (1) terbentuk dari prefiks \{heka-\} digabungkan dengan kata dasar fou'pancing' yaitu hekafui 'memancing'. Data (2) terbentuk dari prefiks \{heka-\} digabungkan dengan kata dasar opi'kaopi (makanan khas dari Kepulauan Tukang Besi yang terbuat dari ubi)' yaitu hekasoami'membuat kasoami'. Data (3) terbentuk dari prefiks \{heka-\} digabungkan dengan kata dasar appa 'paksa' yaitu hekaappa'memaksa-kan'.

Terdapat kata dasar yang tidak dapat bergabung dengan prefiks $\{h e k a-\}$, misalnya:

$\begin{aligned} & \text { buri } \\ & \text { tulis }\end{aligned}$
$\begin{aligned} & \text { sangki } \\ & \text { jahit }\end{aligned}$
$\begin{aligned} & \text { afa } \\ & \text { dapat }\end{aligned}$

\section{Prefiks $\{$ to- $\}$}

Bentuk dasar dalam pembentukan verba dengan prefiks \{to-\}berupa morfem dasar bebas seperti terdapat pada tointe, tomanga, dan tokoni. Bentuk dasarnya berupa morfem dasar bebas: koni, inte, dan manga.

$$
\begin{aligned}
& \text { (1) Inte }, \rightarrow \text { tointe } \\
& \text { 'pergi' } \\
& \text { (2) } \begin{array}{c}
\text { manga } \\
\text { 'makan' }
\end{array} \rightarrow \text { tomanga }
\end{aligned}
$$

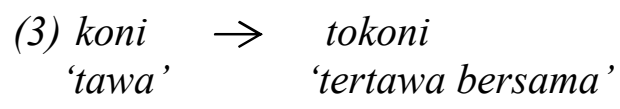

Prefiks \{to- $\}$ bermakna atau berfungsi sebagai kata "ajakan kepada pihak kedua" yang bersama-sama melakukan sesuatu.Ketiga data di atas memiliki pembentukan verba yang sama. Data (1) terbentuk dari prefiks \{to-\} digabungkan dengan kata dasar inte pergi' yaitu tointe'pergi bersama'. Data (2) terbentuk dari prefiks $\{t o-\}$ digabungkan dengan kata dasar manga 'makan ' yaitu tomanga'makan bersama'. Data (3) terbentuk dari prefiks $\{t o-\}$ digabungkan dengan kata dasarkoni'tawa' yaitu tokoni 'tertawa bersama.

Kata dasar seperti di bawah ini tidak bisa bergabung dengan prefiks $\{t o-\}$.

$$
\begin{aligned}
& \begin{array}{l}
\text { toku } \\
\text { buku }
\end{array} \\
& \begin{array}{l}
\text { ufa } \\
\text { uang }
\end{array} \\
& \begin{array}{l}
\text { henai } \\
\text { ajar }
\end{array}
\end{aligned}
$$

\section{Prefiks $\{$ sa- $\}$}

Prefiks sa-bermakna sebagai kata "bilangan satu".
(1) boke
'ikat' $\quad \begin{array}{r}\text { saboke } \\ \text { 'seikat' }\end{array}$
(2) koto $\rightarrow$ sakoto 'potong' 'sepotong' 


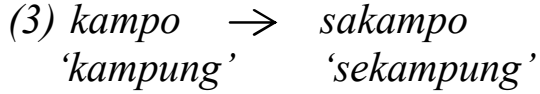

Data (1) terbentuk dari prefiks $\{s a-\}$ digabungkan dengan kata dasar boke'ikat' yaitu saboke'satu ikat'. Data (2) terbentuk dari prefiks $\{s a-\}$ digabungkan dengan kata dasar koto 'potong' yaitu sakoto'sepotong'. Data (3) terbentuk dari prefiks $\{s a-\}$ digabungkan dengan kata dasar kampo 'kampung' yaitu sakampo'sekampung'.

\section{PENUTUP}

Berdasarkan hasil analisis data, dalam bahasa Kepulauan Tukang Besi dialek Kaledupa terdapat delapan prefiks pembentuk verba. Prefiks Pembentuk verba Bahasa Kepulauan Tukang Besi Dialek Kaledupa yaitu prefiks $\{h o n-\},\{n o-\},\{p a-\}$, $\{h e-\},\{p o-\},\{n i-\}$, \{heka-\}, dan \{to-\}.Verba berprefiks \{hon-\} mempunyai makna gramatikal 'melakukan pekerjaan' dan 'melakukan kegiatan'. Prefiks \{no-\} mempunyai makna gramatikal 'sedang melakukan pekerjaan'. Prefiks $\{p a-\}$ mempunyai makna gramatikal 'melakukan pekerjaan' dan 'melakukan kegiatan'. Prefiks \{he-\} mempunyai makna 'sedang melakukan pekerjaan'. Prefiks $\{p o-\}$ mempunyai makna gramatikal 'saling'. Prefiks \{ni-\} mempunyai makna gramatikal pasif 'dikenai laku' atau 'tindakan'. Prefiks \{heka-\} mempunyai makna gramatikal 'melakukan kegiatan'. Prefiks \{to- $\}$ mempunyai makna gramatikal 'ajakan pada pihak kedua'.

Hasil penelitian "Prefiks Pembentuk Verba Bahasa Kepulauan Tukang Besi Dialek Kaledupa" dapat dijadikan referensi untuk penelitian selanjutnya dan dapat memberi ilmu yang bermanfaat kepada pembaca. Hasil penelitian ini masih jauh dari kesempurnaan. Namun peneliti berharap agar hasil penelitian ini dapat memberi informasi tentang bahasa Kepulauan Tukang Besi Dialek Kaledupa kepada pembaca.

\section{UCAPAN TERIMA KASIH}

Syukur Alhamdulillah senan-tiasa penulis panjatkan kehadirat Allah SWT. Yang telah memberikan kenikmatan besar, baik nikmat insan, kesehatan dan kekuatan di dalam penyusunan Jurnal ini. Salawat dan salam senantiasa tercurahkan kepada Nabi Muhammad SAW. Para sahabat dan penegak sunnah-Nya sampai kelak akhir zaman.

Penulis menyampaikan rasa terima kasih yang sebesar-besarnya kepada bapak Nadir La Djamudi, S. Pd, M.Pd yang telah meluangkan waktunya untuk memberikan petunjuk, dorongan, saran dan arahan sejak rencana penelitian hingga selesainya penulisan jurnal penelitian ini. Ucapan terima kasih juga penulis sampaikan kepada kedua orang tuaku Hasidin, Wa Hakki, dan Wa Hajara yang telah memberikan motivasi dan inspirasi dalam menyelesaikan penelitian ini. Terutma kepada adinda Eka Darno, Desi Arisandi yang telah meluangkan waktu untuk mencarikan referensi berkaitan dengan penelitian.

Ucapan terima kasih juga penulis sampaikan kepada:

1. Wa Ode Fidarsi Ali, S. Pd, M.Sos selaku Sekretaris Camat Kaledupa.

2. Seluruh Staf/karyawan Desa di Kecamatan Kaledupa dan Kaledupa Selatan

3. Seluruh Mahasiswa Pascasarjana seangkatan jurusan Bahasa Indonesia Fakultas Ilmu Budaya Universitas Hasanuddin di Makassar yang telah memberikan pelayanan yang baik selama penulis melakukan penelitian.

4. La Hasidi, Wa Hakki, Hajara, Nur Rahmah Al Haqq, Edi Basri, Hasan Basri, Mayana, Eka Darno, Nur Sariati, La Ele, La Ode Masfito, Nuriono, Karim, dan seluruh masyarakat Kaledupa Induk dan Kaledupa selatan selaku informan yang telah memberikanwaktu, kesempatan dalam penelitian ini. 
5. Sahabat-sahabatku Mahasiswa Pascasarjana (angkatan 2015-2016) Nur Rahmah Al Haqq, Nur Sariati, Mutmainnah, Wa Ode Siti Salma, Dian, Rafika, Dian, Budi, Supriadi, Sri Verlin, Sutrisno, Taufik Salamun, Harziko yang dengan penuh keikhlasan membantu penulis.

\section{DAFTAR PUSTAKA}

Chaer, Abdul. 2008. Morfologi Bahasa Indonesia (Pendekatan dan Proses). Jakarta: Rineka Cipta.

Chaer, Abdul. 2009. Sintaksis Bahasa Indonesia. Jakarta: Rineka Cipta.

Darwis, Muhammad. 2012. Morfologi Bahasa Indonesia Bidang Verba. Makassar: Menara Intan.

Djajasudarma, T. Fatimah. 1993. Metode Linguistik: Ancangan metode Penelitian dan Kajian. Bandung:PT Eresco.

Kridalaksana, Harimurti. 2005. Kelas Kata dalam Bahasa Indonesia. Jakarta: Gramedia Pustaka Utama.

Kridalaksana, Harimurti. 2007. Pembentukan Kata dalam Bahasa Indonesia. Jakarta: PT Gramedia.

Kushartanti, dkk. 2005. Pesona Bahasa, Langkah Awal Memahami Linguistik. Jakarta: PT Gramedia Pustaka Utama.
Mahsun, 2007. Metode Penelitian Bahasa: Tahap Strategi, Metode, dan Tekniknya. Jakarta: PT RAJAGRAFINDO PERSADA.

Sidu, La Ode. 2012. Sintaksis Bahasa Indonesia. Kendari: Unhalu Press.

Subroto, Edi. 1992. Pengantar Metode penelitian Linguistik Struktural. Surakarta: sebelas Maret University Press.

Sudaryanto. 1993. Metode dan Aneka Teknik Analisis Bahasa. Yogyakarta: Duta Wacana University Press.

Sutopo, H.B. 1997.Metodologi Penelitian Kualitatif (Metodologi Penelitian untuk Ilmu-Ilmu Sosial dan Budaya). Surakarta: Universitas Sebelas Maret Surakarta Press.

Usman, Moses. 2013. Alat Penganalisis Bahasa-Bahasa di Dunia Morfologi dan sintaksis.Makassar: Alauddin University Press.

Verhaar. 2004. Asas-asas Linguistik Umum. Yogyakarta: Gadjah Mada University Press.

Yuli, Mimin. 2013. Struktur Kalimat Infersi Bahasa Kepulauan Tukang Besi Dialek Tomia. Kendari:FKIP. UHO 